Diabetologia $10,93-96$ (1974)

(C) by Springer-Verlag 1974

\title{
A Simple Method for Determining Plasma Insulin in the Presence of Endogenous Insulin Antibodies
}

\author{
F. I. R. Martin and J. Russell \\ Departments of Endocrinology and Biochemistry, Royal Melbourne Hospital, Melbourne, Australia
}

Received: May 28, 1973, and in revised form: October 15, 1973

\begin{abstract}
Summary. A simple method for the estimation of plasma insulin in the presence of insulin antibodies is described using dilution and dextran-charcoal separation. In 43 non-insulin resistant diabetics the estimated nonextracted (N.E.) insulin was between 69 and $2444 \mu \mathrm{U} / \mathrm{ml}$. N.E. insulin appears to be constantly related to values
\end{abstract}

obtained by acid-alcohol extraction of plasma containing insulin-antibodies, representing about $60 \%$ of total insulin.

Key words: Plasma insulin, insulin antibodies, nonextracted insulin, free insulin.
The determination of plasma insulin by radioimmunoassay (I.R.I.) in the plasma of diabetics treated with insulin has necessitated the separation of the endogenous insulin-antibody complex. Heding $[1,2]$ used acidification, followed by alcohol precipitation and Pearson and Martin [6] gel-filtration, after acidification, to do this. This report describes a method of measuring plasma insulin in the presence of endogenous insulin antibodies by the simple technique of dilution, followed by separation of free and protein-bound insulin with dextran-charcoal. The amount of insulin estimated in plasma by this method represents approximately $60 \%$ of total insulin determined by acid-alcohol precipitation. This has been termed non-extracted (N. E.) insulin.

\section{Methods}

Plasma collected into lithium-heparin tubes was obtained from diabetic patients, treated with insulin, $12-14$ or $24-28 \mathrm{~h}$ after the last injection of a shortacting or medium-acting insulin. As the method described has not been quantitated by specific separation of insulin antibodies, the non-specific term "insulin binding", implying the binding of insulin to plasma proteins is used throughout.

To determine insulin binding in individual plasmas $0.7 \mathrm{ml}$ of ${ }^{125} \mathrm{I}$-insulin $(0.2-0.4 \mathrm{ng}), 0.1 \mathrm{ml}$ plasma and $0.1 \mathrm{ml}$ of buffer were incubated for $48 \mathrm{~h}$ at $4^{\circ} \mathrm{C} .2 \mathrm{ml}$ of dextran-coated charcoal was added and after centrifugation the radio-activity was counted in the chareoal precipitate, free and bound counts were calculated and insulin binding expressed as ; Percent Binding = bound counts/total counts $\times 100$. Plasma from normal people and from diabetics who had not received insulin have always had a binding of less than $5 \%$ by this procedure in our hands. Plasma insulin was measured by radioimmunoassay using dextran-coated charcoal $[3,5]$, porcine insulin iodinated with $\mathbf{1} \mathbf{1 2 5}$ by Chloramine-T, a pork-insulin standard (Lilly Lot PJ5589-25 $\mathrm{I} \mu / \mathrm{mg}$ ) and, a total incubation volume of $1 \mathrm{ml}$, containing $0.1 \mathrm{ml}$ of plasma. The intra-assay error of the method had a coefficient of $5 \%$ and a between assay error coefficient of variation $7.8 \%$, when the final concentration of insulin assayed was between 3 and $40 \mu \mathrm{U} / \mathrm{ml}$.

Plasma insulin was measured in non-extracted plasma obtained from diabetic patients receiving insulin by diluting each plasma in buffer to three dilutions, either $1 / 5,1 / 10,1 / 20$, or $1 / 40$. Plasma concentration was equalized by adding an appropriate volume of pooled plasma to the incubation mixture immediately prior to the addition of dextran-coated charcoal. Both undiluted and diluted samples were then assayed for insulin. The bound counts in the blank samples of plasma at each dilution, determined in duplicate, were subtracted from the normal assay samples to which insulin antibody had been added so that the amount of ${ }^{125}$-I insulin bound to antibody could be determined. In plasma with low binding insulin could be determined with the undiluted sample, but, in most, the estimated level was above the limits of the assay range. By dilution not only was the percentage binding reduced, but the non-extracted insulin was able to be assayed within the standard curve.

Total and "free" insulin were extracted from binding plasmas by the method of Heding (1972). In our hands the performance of this method was similar to that described. Recovery of insulin added to normal plasma was $69 \%$ to $82 \%$ (mean $75 \%$ ) and from binding plasma obtained from diabetics on insulin $76 \%$ to $109 \%$ (mean $95 \%$ ). Assays of serial dilutions of extracts were linear and binding was always less than $4 \%$.

\section{Results}

The assay of insulin in binding plasmas at different dilutions was linear in all cases (Fig. 1). The dilution curve could thus be extrapolated to determine plasma 
insulin in the undiluted sample. To three control plasma samples containing insulin but no insulin antibodies and three binding plasmas containing antibodies, standard pork insulin was added to give final added concentrations of $100 \mu \mathrm{U} / \mathrm{ml}, 500 \mu \mathrm{U} / \mathrm{ml}$ and $1000 \mu \mathrm{U} / \mathrm{ml}$. Samples were then incubated in the normal way and assayed for insulin at appropriate dilution. The re-

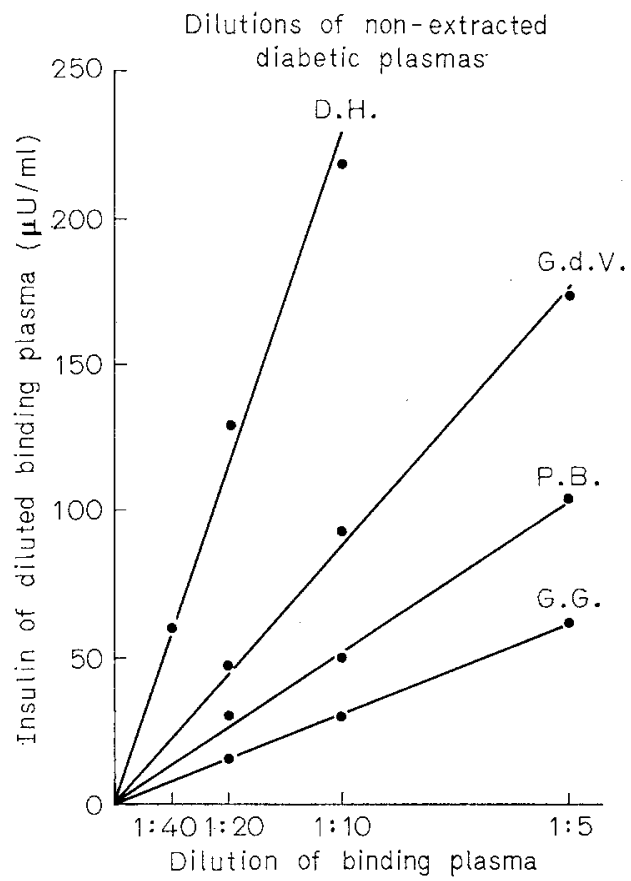

Fig. 1. The assay of N.E. insulin at different plasma dilutions

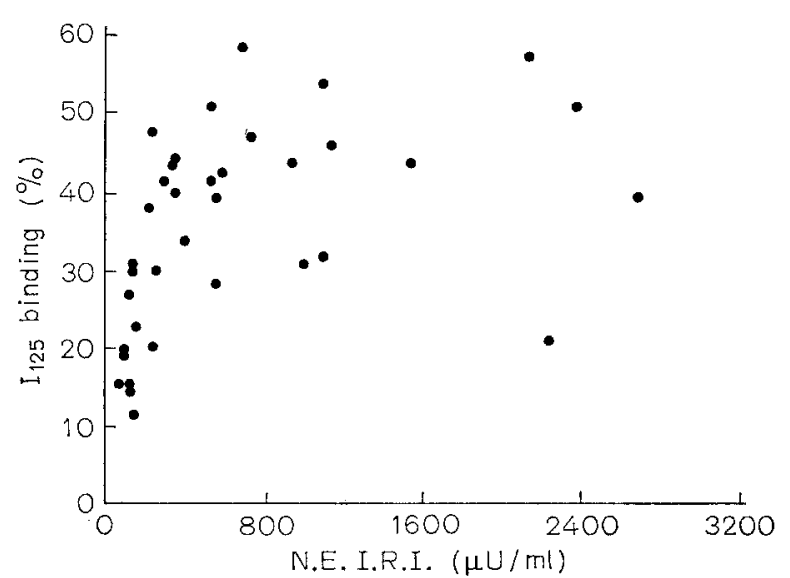

Fig. 2. The relation between N.E. insulin and \% binding of ${ }^{125} I$ insulin $(r=0.738 ; p=<0.001)$ covery $(79-127 \%)$ was similar for both control and binding plasmas (Table 1). The sensitivity of the method determined by the addition of porcine insulin was about $10 \%$, or $25 \mu \mathrm{U} / \mathrm{ml}$ in a sample of binding plasma containing $250 \mu \mathrm{U} / \mathrm{ml} \mathrm{N}$.E. insulin.

In 43 samples obtained from diabetics on insulin there was a significant correlation between percentage

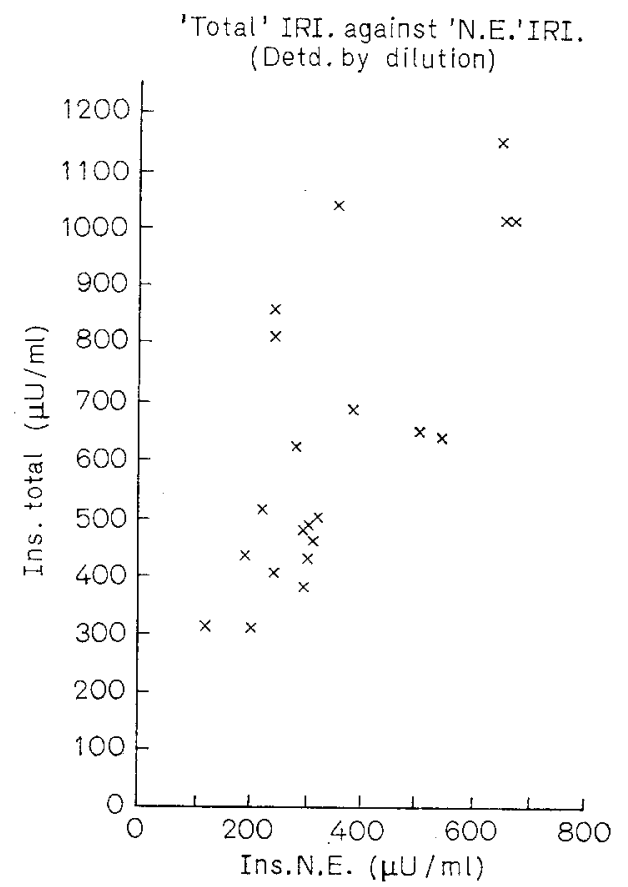

Fig. 3. The relation between total I.R.I. (Heding) and N.E. insulin in 23 diabetics receiving insulin $(r=0.92$; $p=<0.001)$

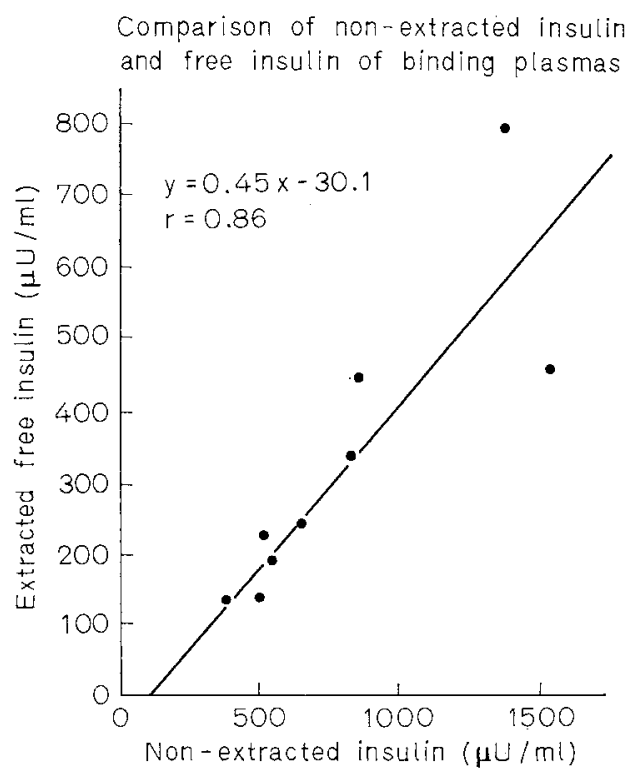

Fig. 4. The relation between "free" I.R.I. (Heding) and N.E. insulin in eight diabetic subjects receiving insulin 
binding and N.E. insulin (Fig. 2), but above a binding of $50 \%$ no further increase in binding was found, despite increasing insulin levels. Plasma insulin measured as N.E. insulin in the 43 diabetics studied was between 69 and $2440 \mu \mathrm{U} / \mathrm{ml}$.

In 23 binding plasmas extracted by acid alcohol total insulin was found to be closely related to N.E. insulin ( $\mathrm{r}=0.92-$ Fig. 3) with a ratio of 1.75:1 (N.E. I.R.I. $=57 \%$ total insulin). In 8 samples in which "free" insulin was also estimated by simple alcohol precipitation N.E. insulin was greater than the "free" fraction, but constantly related, so that "free" I.R.I. represented about $40 \%$ of N.E. insulin (Fig. 4). Con- firmation that the bound/free ratio of insulin remains relatively constant in non-resistant, insulin-dependent diabetics was obtained by directly comparing "free" and total I.R.I. from extractions of the same sample. There was a significant correlation $(\mathrm{n}=8 ; \mathrm{r}=0.89$; $p=<0.01$ ) between them, "free" representing approximately $25 \%$ of the total I.R.I. This relation was illustrated by the study of a young diabetic woman who injected herself with approximately 3000 units of crystalline insulin zinc suspension in a suicidal attempt. N.E. insulin total and "free" insulin and \% binding determined 2 to 7 days after this are shown in Fig. 5. At the time of initial presentation, $48 \mathrm{~h}$ after the

Table 1. Recovery of insulin added to non-extracted binding plasma and control plasma

\begin{tabular}{|c|c|c|c|c|c|c|c|}
\hline & \multirow{2}{*}{$\begin{array}{l}\text { Insulin } \\
\text { added } \\
\mu \mu\end{array}$} & \multicolumn{2}{|c|}{ Experiment 1.} & \multicolumn{2}{|c|}{ Experiment 2.} & \multicolumn{2}{|c|}{ Experiment 3 . } \\
\hline & & $\begin{array}{l}\text { Insulin } \\
\text { obtained } \\
\mu \mu / \mathrm{ml}\end{array}$ & $\begin{array}{l}\text { Recovery } \\
\%\end{array}$ & $\begin{array}{l}\overline{\text { Insulin }} \\
\text { obtained } \\
\mu \mu / \mathrm{ml}\end{array}$ & $\begin{array}{l}\text { Recovery } \\
\%\end{array}$ & $\begin{array}{l}\text { Insulin } \\
\text { obtained } \\
\mu \mu / \mathrm{ml}\end{array}$ & $\overline{\text { Recovery }}$ \\
\hline Insulin & 0 & 383 & & 216 & & 263 & \\
\hline $\begin{array}{l}\text { Binding } \\
\text { Plasma }\end{array}$ & $\begin{array}{r}100 \\
500 \\
1000 \\
0\end{array}$ & $\begin{array}{r}513 \\
858 \\
1376 \\
57\end{array}$ & $\begin{array}{r}106 \\
97 \\
99\end{array}$ & $\begin{array}{r}320 \\
885 \\
1260 \\
54\end{array}$ & $\begin{array}{r}99 \\
124 \\
104\end{array}$ & $\begin{array}{r}359 \\
703 \\
998 \\
70\end{array}$ & $\begin{array}{l}99 \\
92 \\
79\end{array}$ \\
\hline $\begin{array}{l}\text { Control } \\
\text { Plasma }\end{array}$ & $\begin{array}{r}100 \\
500 \\
1000\end{array}$ & $\begin{array}{r}199 \\
545 \\
1105\end{array}$ & $\begin{array}{r}127 \\
98 \\
105\end{array}$ & $\begin{array}{l}171 \\
465 \\
973\end{array}$ & $\begin{array}{r}111 \\
84 \\
92\end{array}$ & $\begin{array}{r}160 \\
620 \\
1095\end{array}$ & $\begin{array}{r}94 \\
109 \\
102\end{array}$ \\
\hline
\end{tabular}

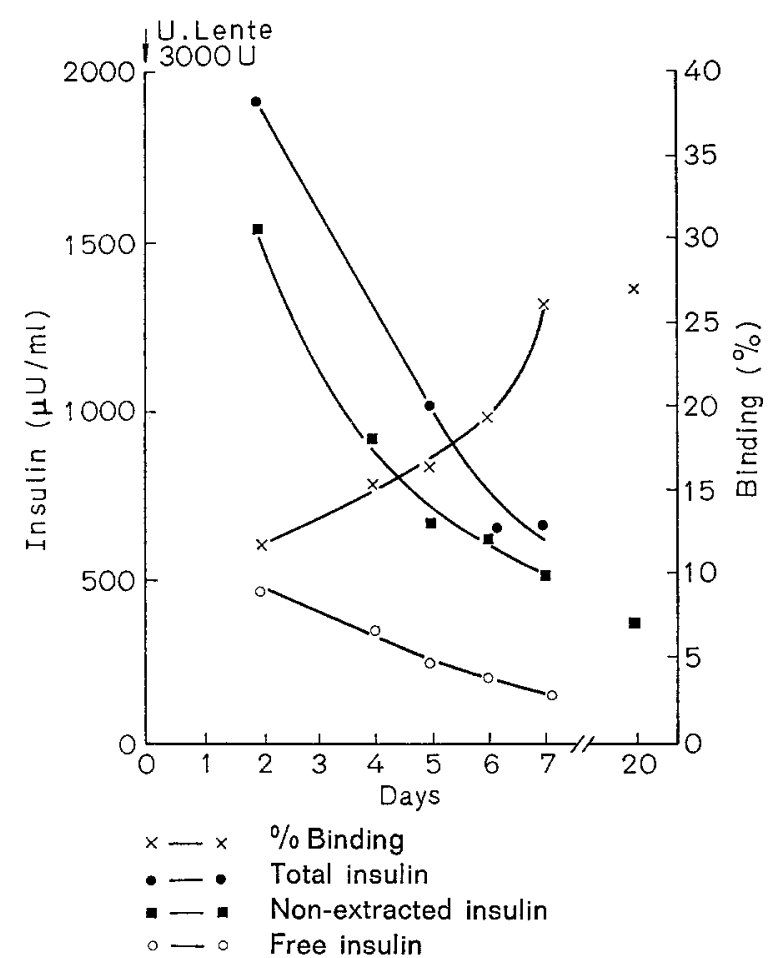

Fig. 5. Changes in N.E. insulin $\mathbf{- n}$; total I.R.I. "free" I.R.I. o-o; and \% binding ${ }^{125} \mathrm{I} x-\mathrm{x}$; following the injection of 3000 units Ultra-Lente insulin in a diabetic female episode, she had severe but easily treatable hypoglycaemia, which persisted until $96 \mathrm{~h}$; no further insulin was required until 10 days after the episode. The parallel changes in N.E. insulin, total and "free" insulin are all apparent, with a reciprocal increase in $\%$ binding to decreased plasma insulin.

One patient with severe insulin resistance requiring 1500 units of insulin a day was studied. N.E. insulin was $99000 \mu \mathrm{U} / \mathrm{ml}$, total I.R.I. $200000 \mu \mathrm{U} / \mathrm{ml}$ and "free" I.R.I. $13000 \mu \mathrm{U} / \mathrm{ml}$.

\section{Discussion}

The estimation of plasma N.E. insulin in insulin. binding plasma obtained from diabetic subjects receiving insulin by simple dilution and dextran-charcoal separation gives consistent results. The validity and reproducibility of the method were verified by dilution and recovery studies. Whether more prolonged incuba. tion would lead to increased dissociation of the endogenous insulin-antibody complex is uncertain, but comparison of 5 day versus 2 day incubates on two occasions did not reveal any evidence that this occurred.

The range of fasting plasma insulin measured as N.E. insulin by immunoassay in 45 non-insulin resistant subjects whose insulin dose was between 24 and 96 units a day was 69 to $2440 \mu \mathrm{U} / \mathrm{ml}$. Com- 
parative velues for total insulin in similar patients by other methods are $6-4347 \mu \mathrm{U} / \mathrm{ml}$ alcohol precipitation [2] and $700-6000 \mu \mathrm{U} / \mathrm{ml}$ by gel-filtration [6]. There was a close relation between N.E. insulin and both the total and "free" insulin determined by $\mathrm{He}$ ding's alcohol, acid-alcohol precipitation method. N.E. insulin represented $57 \%$ of total insulin and "free" insulin $40 \%$ of N.E. insulin. The implied constant relation between free and total insulin was confirmed directly in a small number of plasma samples and in one patient where serial estimates of N.E., total and free I.R.I. were made after a suicide attempt. These results suggest that in non-insulin resistant diabetics antibodies produced by exogenous insulin have relatively constant dissociation between free and bound insulin. This is in agreement with the lack of any relation between acute insulin sensitivity and antibody titres and the commonly observed constancy of insulin dose in stable diabetic subjects, which appears unrelated to antibody titre $[2,4,6]$. Extrapolation of these "in vitro" results to clinical situations must be balanced by the possibility of marked changes in the kinetics of the insulin-antibody complexes. However, it is of interest that in the patient with severe insulin resistance "free" insulin represented only $7 \%$ of total I.R.I.

Previous reports of the measurement of insulin by direct immunoassay in the presence of insulin antibodies have used double-antibody precipitation [4] and chromato-electrophoresis [7]. With the former method an increased recovery of added insulin was observed at high levels, but with the present method recovery was linear up to $1000 \mu \mathrm{U}$. insulin per $\mathrm{ml}$. Whether this is due to the absorption of endogenous human insulin antibodies by charcoal and their failure to precipitate with the "second" anti-globulin antibody is uncertain. As observed by Moxness et al. [4] there was a close relation between the percentage binding to dextran-charcoal and N.E. I.R.I. up to estimated I.R.I. values of $750 \mu \mathrm{U} / \mathrm{ml}$. Above 50\% binding the estimated binding did not increase, despite greatly increased I.R.I., which in one case of insulin resistance was $99000 \mu \mathrm{U} / \mathrm{ml}$. Further work is required to establish the relation between I.R.I. and insulin antibody titre determined specifically by immunoelectrophoresis, as separation by dextran-charcoal does not differentiate between specific antibody binding and other plasma protein binding of insulin. The serial studies on the patient who injected herself with a huge amount of insulin in a suicidal attempt showed that there was a reciprocal relation between percentage binding and N.E. I.R.I. over a ten day period of observation. Her recovery after the injection of approximately 3000 units of insulin zinc-suspension crystalline was no doubt due to the buffering effect of the insulin antibodies as well as to the delayed absorption of the insulin.

We conclude that the estimation of N.E. insulin by the dilution technique using dextran-charcoal separation provides a useful clinical estimate of plasma insulin in the presence of insulin antibodies. The method is simple and uses only $0.2 \mathrm{ml}$ of plasma for duplicate determinations of both N.E. insulin and percentage binding of added $\mathrm{I}^{125}$ insulin to plasma protein.

Acknowledgements. We are grateful to Dr. H. Breidahl for providing plasma from the insulin-resistant patient and to Miss Margaret Pearson and Dr. C.W. Baird for discussion and criticism of this work.

\section{References}

1. Heding, L.G.: Determination of free and antibody bound insulin in insulin treated diabetic patients. Horm. Metab. Res. 1, 145-146 (1969)

2. Heding, L.G.: Determination of total serum insulin (I.R.I.) in insulin treated diabetic patients. Diabetologia 8, 260-266 (1972)

3. Herbert, V., Lau, K., Gottlieb, W., Bleicher, S.J.: Coated charcoal immunoassay of insulin. J. clin. Endocr. 25, 1375-1384 (1965)

4. Moxness, K.E., Molnar, S.D., Taylor, W.F., Owen, C. A., Ackerman, S., Rosevear, J.W.: Studies of diabetic instability. I. Immunoassay of human insulin in plasma containing antibodies to pork and beef insulin. Metabolism 20, 1074-1082 (1971)

5. Pearson, M.J., Fullerton, M.J., Martin, F.I. R., Melick, R.A.: An assessment of the charcoal immunoassay of insulin. Proc. Aust. Ass. clin. Biochem. 1, 315-319 (1968)

6. Pearson, M.J., Martin, F.I.R.: The separation of total plasma insulin from binding proteins using gel filtration; Its application to the rate of insulin disappearance. Diabetologia 6, 581-585 (1970)

7. Yalow, R.S., Berson, S.: Immunoassay of plasma insulin in man. Diabetes $10,339-344$ (1961)

Dr. F.I.R. Martin

Dept. of Endocrinology

Royal Melbourne Hospital

Victoria 3050

Australia 